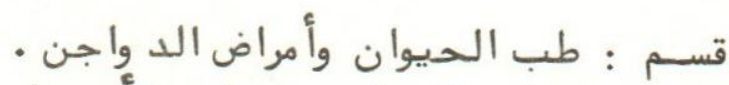

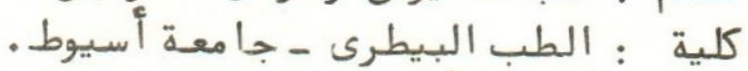

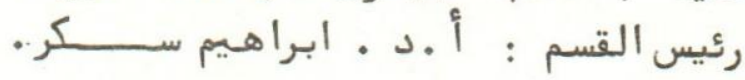

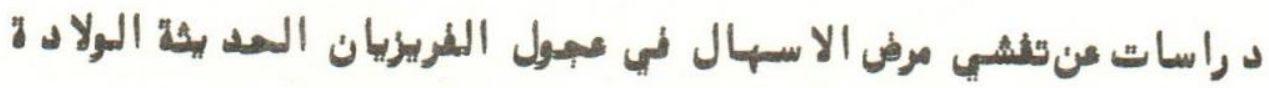

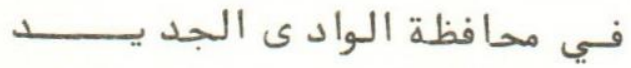

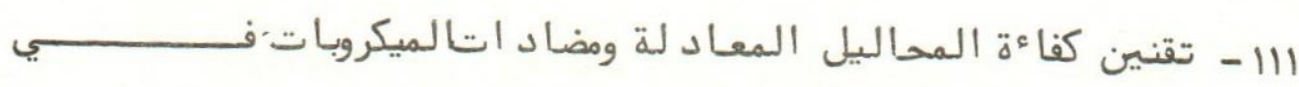

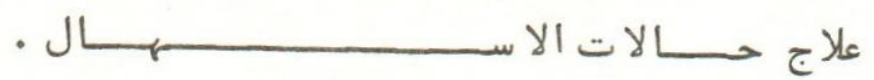

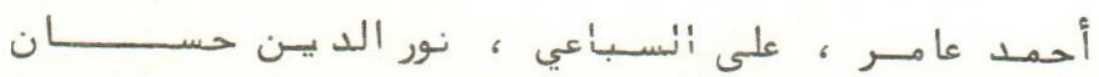

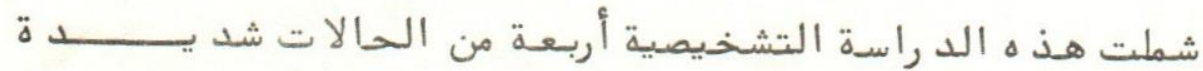

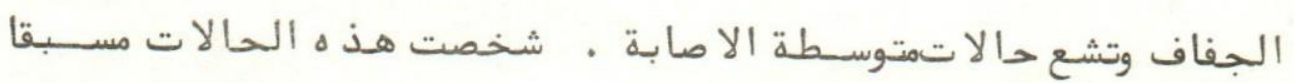

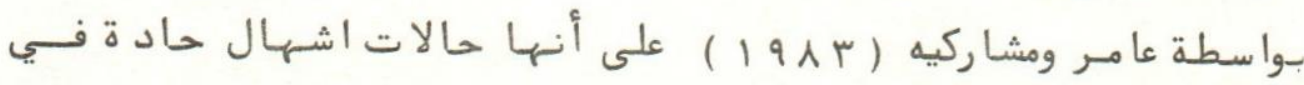

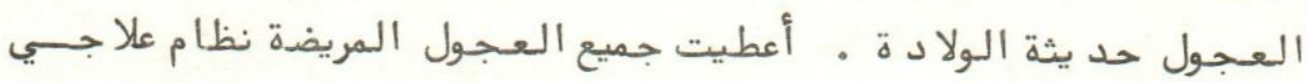

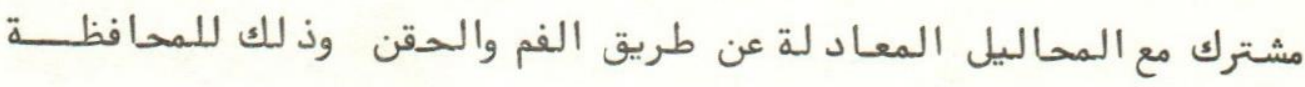

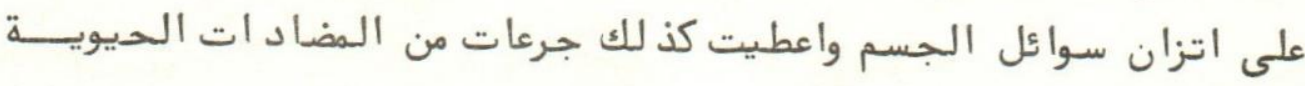

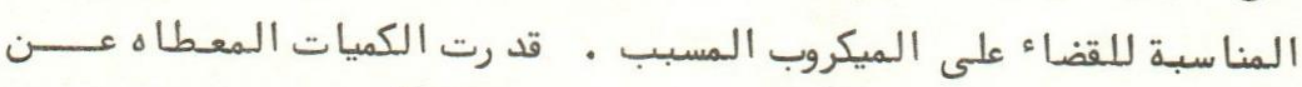

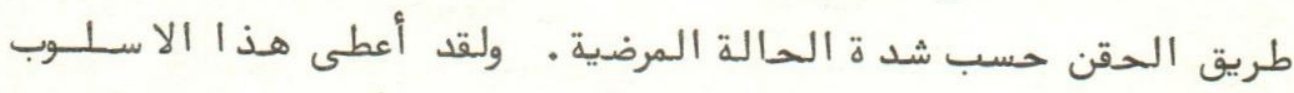

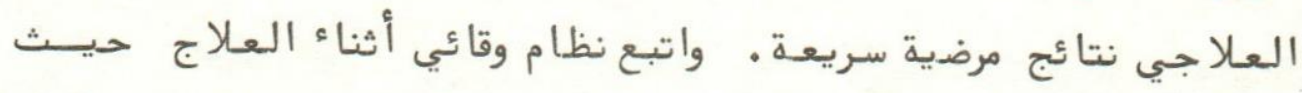

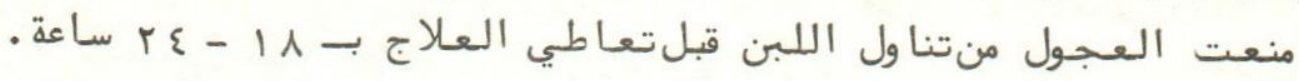

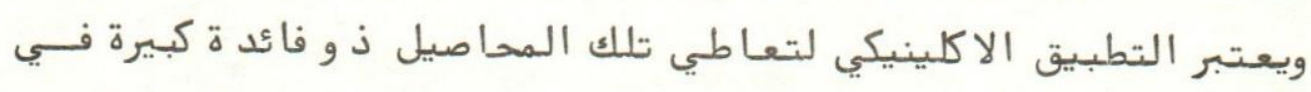

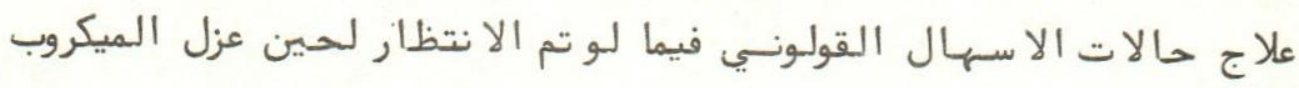


Dept. of Medicine \& Poultry Disease, Faculty of Vet. Med., Assiut University, Head of Detp. Prof. Dr. I. H. Sokkar.

\title{
STUDIES ON AN OUTBREAK OF COLIBACILLOSIS AMONG NEWLY BORN HOLSTEIN FRIESIAN CALVES IN THE NEW VALLEY, EGYPT III. EVALUATION OF ADMINISTERED BALANCED ELECTROLYTES IN CONJUNCTION WITH ANTIMICROBIAL AGENTS IN THE TREATMENT OF ACUTE ENTERIC COLIBACILLOSIS \\ (With 3 Tables)
}

\author{
By \\ A.A. AMER; A. EL-SEBAIE and N.K. HASSAAN \\ (Received at 9/4/1983)
}

\begin{abstract}
SUMMARY
A clinical trial involved four severely dehydrated calves and nine moderately dehydrated calves. Both were affected with acute neonatal diarrhoea AMER; HASSAAN; EL-SEBAIE; BAYOUMI and IBRAHIM (1983). All calves were given a combinations of prepared oral electrolytes, parenteral balanced electrolytes, to correct dehydration and maintain hydration, in conjunction with the antibiotic of choice at adequate dose levels. The amounts given calculated according to the severity of dehydration. The intravenous route of administration in this trial gave quick and encouraging results. Calves were starved for 18-24 hours, not allowed any milk. Both the treatment and control of diarrhoea in the affected calves are difficult and frustrating because often the cause of diarrhoea can not be determined quickly and accurately, nevertheless following this infusion therapy regimen clinical, spectacular results were achieved.
\end{abstract}

\section{INTRODUCTION}

Neonatal diarrhoea is not a modern disease. Under various names it has been registered as important disorder for cattle since so many years. Although the pattern had changed with the new methods of calf rearing and husbandry, nevertheless the practising veterinarian, still faced disappointment and indeed headaches in the treatment of these conditions. With the discovery of penicillin and other antibiotics, it was believed that the disease would be brought under control (OTTSON, 1959), however, the incidence of diarrhoea appears to be increasing.

Despite the great variety of therapeutic agents in current use; EDGSON (1964), there has been a steady development of strain of bacteria resistant to the drugs used. Antibiotics added to the diet to produce increased weight gains; (MOORE, EVENSON, TUCKY, MCCOY, ELVEHJEM and HART 1946); have contributed to that development. It has been found that the members of antibiotic resistant strains of E.coli isolated from calves were increasing (SMITH and CRABB, 1956) and further that the increase was probably due in some instances to the mutation of drugsensitive strains. Of great interest to mention that DALTON, FISHER and MC INTYRE (1960) demonstrated that antibiotics given prophylactically in therapeutic doses were of use in preventing the colibacillosis syndrome, but the cost and the probability of resistance developing would lead to a search for another methods of control.

Assiut Vet.Med.J. Vol. 14, No. 27, 1985. 
A.A. AMER, et al.

WATT (1965) stated that the problem of treating a calf demonstratinc thit amotums of diarrhoea is to find a therapy which will give immediate help to the animai irrespertue of the underlying cause of disorder. He added that the administration of fluids contaming water and electrolytes is an important and necessary part of treatment, which unfortunately has bean: regiented by most veterinarians.

Owing to the fore-going uncertainty concerning current treatment and controt ut neonata: diarrhoea in calves, it was decided to investigate the effect achieved by correcturg the thic and electrolyte imbalance using a prepared electrolyte solution in conjunction with the chemotherapeutic agent of choice for treatment of such outbreaks. This work is also designed to discuss in simple term the clinical indications, types of fluids and the methods of administration that are employed in case assessment and management.

\section{MATERIAL and METHODS}

\section{ANIMALS:}

Full details on the unhealthy dierrhoerc calves as well as apparently healthy ones were pre:ously stated by AMER, HASSAAN, EL-SEBAIE, BAYOUMI and IBRAHIM .1983).

\section{Design of fluid therapy Regimen:}

A balanced electrolyte solutions (Tables I, II \& III were prepared in conjunction with the antibiotics at adequate dose levels results, dependent on the degree of dehydration. Because most. calves (severely and moderately dehydrated) showed losses of sodium, chloride and potassium (HASSAAN, EL-SEBAIE and AMER, 1983), it is essential that the fluid must contain sufficient of these elements to effect repair. A more eleborate solution capable of supplying all the electrolyte deficits specially sodium potassium and chloride is that designed in our laboratory. This is made by the inclusion of intracellular cations in the replacement fluid. The remainder being given as $5 \%$ glucose solution. Chloramphenical was the antibiotic of choice selected in this study.

\section{Route of Administration:}

For both conditions, they were given oral and parenteral fluid therapy. The intravenous route using the slow drip was the route used in the delıvery. Animals were restramed in lateral recumbency, their legs were tied together and the head was secured with a halter tied to a post. Initially the rate at which the fluid is administered should be carefully supervised, least acute venous congestion occurs, then the flow should be increased gradually to about $6 \mathrm{ml} / \mathrm{min}$. 50 drop from standard drip set). Once 150 to $200 \mathrm{ml}$ have been infused, the flow late can be increased to the medium capable of delivery by the apparatus under gravity flow. After 400 to $600 \mathrm{mi}$ have been infused, the rate should be reduced to $2-3 \mathrm{ml} / \mathrm{mm}$. and $\mathrm{kept}$ at this rate or slightly slower throughout the remainder of the infusion. Having achieved the first stage of repair the rernalrung problem is to hydrate the tissues and replace some of the electrolytes which have occurred.

\section{RESULTS}

\section{Group I:}

Four calves severely dehydiated were subjected to fluid regimen. Each calf receried onit gailon orai electrolyte solution per $50 \mathrm{~kg}$. body weight in divided doses for the first 24 hour from the ommencement of treatment as well as 1.1 of $50 \mathrm{ml}$. balanced electiotyte soiution pet: 


\section{CAL VES COLIBACILLOSIS FLUID THERAPY}

$0.5 \mathrm{~kg}$. body weight in the first $4-6$ hours followed by $70 \mathrm{ml}$ per 0.5 body weight. Chloramphenicol is given as the drug of choice (Table III). The period of treatment lasted for seven days. The survival rate was high.

\section{Group il:}

Nine calves comprised this group. Each calf received the same schedule of treatment as the first group with exception of infusing $25 \mathrm{ml}$. balanced electrolyte solution per $0.5 \mathrm{~kg}$ body weight for the first 4-6 hours of treatment followed by $70 \mathrm{ml}$ per $0.5 \mathrm{~kg}$ body weight. The period of treatment lasted for four days.

During the first 24 hours of drip infusion it was difficult to feed calves affected because it is usually ill and not interested in food. Forced feeding is usually resisted and is best avoided. After administration in every instance, there was marked improvement and in 12 hours schedule of treatment, the calves of the group II were able to stand unassisted, the eyes which were sunken previously returned to their normal position. In the majority of both groups, the dehydration is eliminated. For group I (severely dehydrated) a further period of 72 hours infusion is prescribed and this resulted in recovery in most cases.

The professional and technical man hours were necressary to conduct the trial were enormous but interesting as it required one veterinarian and two animal technicians on a full-time basis working a minjmum of 10 hours per day and more frequently 12 hours or more per day. The technicians fed the calves, maintained the fluid therapy, administered the antibiotics and did most of record keeping, while the veterinarians, evaluated the calves clinically, initiated the intravenous fluid therapy and monitored the clinical response.

\section{DISCUSSION}

\section{Clinical Indication:}

The problem of examining and treating eouring in a group of calves is faced with a two-folds problem; first to find and calculate a therapy which will give immediate help to the animal irrespective of the underlying cause of disorder, secondly, to arrive at an accurate diagnosis of the aetiological factor(s).

The assumption that the PCV changes are exactly mirrored throughout the tissues and that the fall in circulatory volume is entirely due to a fall in plasma volume are not strictly correct but sufficiently accurate for the purpose of the design of a fluid replacement regimen to suit the average individual. By measurement of the PCV it is possible to estimate the degree of dehydration of any individual animal (AMER et al. 1983) and with experience it is possible to correlate the clinical condition of the calf with its PCV. This means that even without the advantage of knowing the accurate PCV, it is possible in clinical practice to arrive at a ressonably accurate prognosis. In the authors opinion, one must be stressed that for clinical evaluation of calves undergoing fluid replacement estimation of PCV with the modern microhaematocrit centrifuge, this procedure is within the economic and practical limits of the practising veterinarian and can be executed on the premises of the stock owner in a few minutes.

\section{Types of fluid:}

A fairly comprehensive range of electrolye preparations are available from commercial source for the repaip of the deficit arising from diarrhoea in calves, but in the authors opinion, they are expensive and exceeded the economic limit specially in severe outbreaks which must be observed in the clinical treatment of these animals. It is evident from the cations and anions that comprised both the oral electrolyte (Table I) and the balanced electrolyte solutions (Table II) play in 


\section{A.A. AMER, et al.}

our opinion a great role in the treatment regimen. Its composition is similar to that of the extracellular fluid, and can recompensate the severe fluid loss and the remarkable losses of sodium and chlorides (HASSAAN et al. 1983). Our results illustrated in Table I and II are in consistent with those of ROY, SCHILLAM, HAWKINS, LANG and INGRAM (1959) that the content of potassium added to the balanced electrolyte solution must be not so high that the plasma level of this electrolyte rises to dangerous levels, for it is fairly certain that this factor coupled with the expected metabolic acidosis may precipitate death by heart failure. The study of AMER et al. (1983) in a previous paper would confirm this hypothesis.

As the animals were in a state of medical shock in particularly the severely dehydrated calves and most of them showed obvious hypoglycaemia (HASSAAN et al. 1983), so the addition to the oral electrolyte solution of a $50 \mathrm{~g}$. glucose for each liter will be of great value for treating the state of energydeficiency. An addition of sodium bicarbonate to the oral electrolyte (Table 1) seem to be of great value for treating the expected metabolic acidosis.

Of clinical interest to report here that GREEN (1964) advocated the use of plasma in conjunction with electrolyte solutions without the addition of antibiotics. This formula achieved Remarkable results in treating an outbreak of scours in calves without significant alteration in the survival rate. THOMPSON (1965) preferred saline solutions. The latter author had used this method satisfactorily in treating a collapsed dehydrated calf. WATT (1967) in comparison studies of various combination of therapies for the treatment of neonatal diarrhoea in calves concluded that plasma was a necessary adjunct to fluid replacemement therapy as the author suspected that plasma contained a factor or factors which were able to exert a therapeutic effect distinct from the effect of fluid replacement. In our opinions some problems regarding plasma therapy may face the veterinarian in the field; firstly the enormous amount of blood collected and that needed to be centrifuged for plasma collection; Secondly, it may produce protein shock if administered intravenously; thirdly, the establishments of plasma banks is not an easy matter as those of fluid therapy. The author added that the comparison trial also revealed that antibiotic therapy, the conventional treatment for neonatal diarrhoea, did not have a significant effect synergistic with the fluid replacement regimen. On the contrary the author stated that inclusion of antibiotics in the regimen; they appeared to have a deleterious effect upon many individuals. Our results and those of RADOSTITS (1965) indicated that the administration of antibiotic therapy in neonatal diarrhoea is essential as it prevents septicaemia, bacteraemia and localization of bacteria in joints, meninges, ocular tissues, and other sites such as feet and tail.

\section{Route of Administration:}

Assuming that an estimate of the amount of fluid has been made, based on the apprasial of the percentage dehydration of the animal, how should it be given. Regarding the oral electrolyte solution for treating the calf diarrhoea, this is in our opoinion a very fast and easy operation specially when kept in mind that a dehydrated calf needs 2 gallons of fluid for replacement to recompensate for continuing losses for the next 10 hours.

TAOMPSON (1965) preferred the intremuscular route of administration to which hyaluronidase had been added. The rate of absorption was speeded up that no reservoir of fluid accumulated at the site of injection. Our opinions are in disagreement, as how the practitioner would give six liters of fluid this way. We have the feeling that there will be not enough deep intramuscular tissues in the calf capable of receiving six Liters fluid replacement therapy. Another reason we give that most of the animals surfered severe diarrhoea are in a state of medical shock with 


\section{CALVES COLIBACILLOSIS FLUID THERAPY}

a certain degree of circulatory collapse, so the first stage of replacement must be aimed at increasing the plasma volume as soon as possible to near normal and the intramuscular route even the subcutaneous route will not fulfill this purpose. The intraperitoneal route in the author's opinion is not so widely used and is not recommended since it is possible to damage internal organs with the infusion needle and certain fluids eg. plasma extenders are not absorbed by this route.

The introvenous route used in our trial gave satisfactory results as the operation is more comfortable Ninety drops a minute will deliver about $300 \mathrm{ml}$. per hour and thus it will take about 12 hours to deliver a gallon of solution to the affected animal. In this way the viscosity of the blood is reduced so that it can flow more easily and relieve some of the strain upon the heart which results from increased viscosity. At the same time capillary beds will be opened and relieved of their burden of stagnant erythrocytes which further impeds the circulation. As the capillaries are reopened, the perfusion of the tissues is improved and usually the extremities become warmer. Of noteworthy here to mention that during the first 24 hours of drip infusion, it was difficult to feed the calf treated as it "was usually too till to be interested in food, so we advised the technicians to withheld food supply. This period of rest for the alimentary tract in the opinion of WATT (1965) appears to be beneficial for most calves schowing a cessation of scours when alimentation is resumed. It also allows time for the cycle of increased peristalsis to subside and to initiate healing of any ulcers or excoriations of the gut wall.

Our studies and those of others (COVAN and DARROW, 1946; SMITH, 1962; WATT, 1967; CARTER, 1969 and CLARK, 1980) demonstrate the dignificance of fluid electrolyte disturbances in the pathogenesis of neonatal enteric infections and emphasize the primary importance of fluid therapy in the clinical management of this groups of diseases.

\section{REFERENCES}

Amer, A.A.; Hassaan, N.K.; El-Sebaie, A.; Bayoumi, A.H. and Ibrahim, A.A. (1983): Studies on an Outbreak of colibacillosis among Friesian calves in the New Valley, Egypt. I. clinical Haematological, aetiological and Pathological alterations. Assiut Vet. Med. J. (Under Publication).

Carter, J.M. (1969): Fluids- The solution for young and Old. J.A.V.M.A., 154, 10: 1168.

Clark, A.M. (1980): Parenteral fluid therapy in small animals. Vet. Rec., 106: 146.

Dalton, R.G.; Fisher, E.W. and Mc Intyre, W.I.M. (1960): Antibiotics and calf diarrhoea. Vet. Rec., 72: 1186.

Edgson, F.A. (1964): Enteric Infections. Vet. Rec., 76: 1351.

Govan, C.D. and Barrow, D.C. (1946): The use of potassium chloride in the treatment of dehydration of diarrhoea in infants. J. Pediat., 28: 541.

Green, B.J. (1964): Vet. Rec. 76: 1102. Cited from Watt, J.G. (1965).

Hassaan, N.K.; El-Sebaie, A. and Amer, A.A. (1983): Studies on an outbreak of colibacillosis among holstein Friesian calves in the New Valley, Egypt. II. Some serum Biochemical and electolyte, changes. Assiut Vet. Med. J. (Under Publication).

Moore, P.R.; Evenson, A.; Tu ckey, T.D.; Mc. Coy, E.; Elvehjem, C.A. and Hart, E.R. (1946): Use of sulphasuxidine, strepotothricin and streptomycin in nutritional studies with the chick. J. Biol. Chem. 165: 435.

Ottsen, H.E. (195,9): Some statistics on calf Mortality. Nord. Vet. Med., 11: 493.

Radostits, O.M. (1965): Clinical management of neonatal diarrhoea in calves, with special reference to pathogenesis and diagnosis. J.A.V.M.A., 147: 1367.

Assiut Vet.Med.J. Vol. 14, No. 27, 1985. 


\section{A.A. AMER, et al.}

Roy, J.H.B.; Shillam, K.W.G.; Hawkins, G.M.; Lang, J.M. and Ingram, P.L. (1959): The effect of white scours on the sodium and potassium concentration in the serum of New-Born caives. Brit. J. Nutr., 13: 219.

Smith, H.W. and Crabb, W.E. (1956): The sensitivity to chemotherapeutic agents of a further series of strains of bacterium coli from cases of white scours, the relationship between sensitivity tests and response to treatment. Vet. Rec., k 68: 274.

Thompson, P.K. (1965): Vet. Rec., 77, 49: 1482, Cited from Watt, J.G. (1965).

Watt, J.G. (1967): Fluid therapy for dehydration in calves. J.A.V.M.A., 150, 7: 742.

Table (1): Oral eledrolyte formula

\begin{tabular}{ll}
\hline Sodium chloride & $117.0 \mathrm{~g}$ \\
Potassium chloride & $150.0 \mathrm{~g}$ \\
Sodium bicarbonate & $168.0 \mathrm{~g}$ \\
Potassium dibasic phosphate & $135.0 \mathrm{~g}$ \\
\multicolumn{1}{c}{ Total } & $570.0 \mathrm{~g}$ \\
\hline
\end{tabular}

For $1000 \mathrm{ml}$ of solution add $5.7 \mathrm{~g}$ of powder to which may be also added $50 \mathrm{~g}$ of glucose. For one gallon $30 \mathrm{~g}$ of powder and $220 \mathrm{~g}$. glucose per $50 \mathrm{~kg}$. body weight in divided doses. 


\section{CALVES COLIBACILLOSIS FLUID THERAPY}

Table (II): Chemical composition of balanced electrolyte solution

\begin{tabular}{lr}
\hline Sodium chloride & 5.50 \\
Calcium chloride & 0.30 \\
Magnesium chloride & 0.30 \\
Sodium acetate & 6.10 \\
Potassium acetate & 1.00 \\
Water & ad liter \\
\hline
\end{tabular}

Table (III): Condition, design of treatment used intreating calves

\begin{tabular}{|c|c|c|c|}
\hline Animal & Oral therapy & Parenteral therapy & Antibiotic therapy \\
\hline \multicolumn{4}{|l|}{ States No. } \\
\hline $\begin{array}{c}\text { Moderately } \\
\text { dehydrated } \\
\text { (9) }\end{array}$ & $\begin{array}{l}\text { One gallon } / 50 \mathrm{~kg} \text { body } \\
\text { weight in divided does } \\
\text { ( } 24 \text { hours })\end{array}$ & $\begin{array}{l}1-25 \mathrm{ml} / 0.5 \mathrm{~kg} . \text { B.w. for } \\
\text { the first } 4-6 \mathrm{hrs} \text { i.v. } \\
\text { 2-70 ml } / 0.5 \mathrm{~kg} \text {. B.w. } \\
\text { i.v. }\end{array}$ & $\begin{array}{l}\text { Chloramphemicol } \\
10 \mathrm{mg} / 0.5 \mathrm{~kg} \text { B.W. } \\
\text { i.v. every } 8 \text { hours } \\
\text { and } 15-30 \mathrm{mg} / 0.5 \\
\mathrm{~kg} \text { B.W. orally }\end{array}$ \\
\hline $\begin{array}{l}\text { Severly } \\
\text { dehydrated } \\
\text { (4) }\end{array}$ & $\begin{array}{l}\text { one gallon } / 50 \mathrm{~kg} . \text { B.W. } \\
\text { in divided doses } \\
\text { ( } 24 \text { hours })\end{array}$ & $\begin{array}{l}1-50 \mathrm{ml} / 0.5 \mathrm{~kg} . \text { B.W. } \\
\text { for the first } \\
4-6 \mathrm{hrs} . \text { i.v. } \\
\text { 2-70 ml/0.5 kg. B.W. } \\
\text { i.v. }\end{array}$ & as above \\
\hline
\end{tabular}

Assiut Vet.Med.J. Vol. 14, No. 27, 1985. 
